\title{
IAEA inter-laboratory comparisons of geothermal water chemistry: critiques on analytical uncertainty, accuracy, and geothermal reservoir modelling of Los Azufres, Mexico
}

\author{
Comparación inter-laboratorios del OIEA para la química del agua \\ geotérmica: críticas sobre la incertidumbre analítica, la precisión y el \\ modelado del yacimiento geotérmico de Los Azufres, México
}

\author{
M. P. Verma \\ Geotermia, Instituto de Investigaciones Eléctricas, Reforma 113, Col. Palmira, Cuernavaca, Morelos, 62490, México. \\ e-mail: mahendra@iie.org.mx
}

Received: 16/05/2011 / Accepted: 12/04/2013

\begin{abstract}
The results of International Atomic Energy Agency (IAEA) inter-laboratory comparison program reported in the literature during 1992 and 2004 were analyzed to estimate analytical uncertainty in the geochemical analysis of geothermal waters. Statistical data treatments for the detection and elimination of outliers and extremums were performed using five methods: (i) data visualization (or raw data statistics); (ii) mean $(\bar{x})$ and standard deviation $(s)$ calculation after eliminating outliers with $\bar{x} \pm 2 s$; (iii) median and median absolute difference (MAD); (iv) Huber method; and (v) single-outlier type multiple test method involving Dixon, Grubbs, skewness and kurtosis tests at 99\% confidence level. The results are reported in scientific notation with one significant digit of uncertainty. A comparative study of all the five statistical data treatment methods suggests that the fifth method provides better results for the statistical analysis of experimental measurements. A preliminary evaluation for the analytical accuracy of geochemical analysis of geothermal waters, prepared by dissolving $4.585 \mathrm{~g} \mathrm{CaCl}_{2}(98.2 \%), 16.5 \mathrm{~g} \mathrm{NaCl}(99.9 \%), 3.58 \mathrm{~g} \mathrm{MgCl}$ (99.0\%), $0.74 \mathrm{~g} \mathrm{Na}_{2} \mathrm{SO}_{4}$ $(99.0 \%)$ and $0.95 \mathrm{~g} \mathrm{KCl}(99.5 \%)$ in 1 liter of solution, is presented. The analysis of $\mathrm{Na}^{+}$and $\mathrm{K}^{+}$are reasonably accurate, while $\mathrm{Mg}^{2+}$ and $\mathrm{SO}_{4}^{2-}$ have high inaccuracy. The accuracy of $\mathrm{Ca}^{2+}$ and $\mathrm{Cl}^{2}$ analyses is in-between. A systematic analysis of the results suggests that the present inaccuracy in the measurements of $\mathrm{Mg}^{2+}, \mathrm{Ca}^{2+}, \mathrm{SO}_{4}^{2-}$ and $\mathrm{Cl}$ are probably associated with the sample preparation. The relations between the coefficient of variation (i.e. \% analytical uncertainty) and concentration of each element are derived, which are used for the propagation of uncertainty in the geochemical calculations of geothermal systems. The uncertainty propagation procedure is illustrated in the calculation of Los Azufres geothermal reservoir temperature and vapor fraction. The uncertainty in the estimated temperature is $\pm 20 \mathrm{~K}$, which means that the changes in the geothermal reservoir fluid characteristics during its exploitation are generally within the uncertainty.
\end{abstract}

Keywords: analytical accuracy, DODESSYS, geothermal waters, Inter-laboratory comparison, statistical data treatment, uncertainty propagation.

\section{Resumen}

Los resultados del programa de comparación inter-laboratorios del Organismo Internacional de Energía Atómica (OIEA), reportados en la literatura durante el período 1992 y 2004, han sido analizados para estimar la incertidumbre en los análisis geoquímicos de las aguas geotérmicas. Se realizó el tratamiento estadístico de los datos para la detección y eliminación de valores atípicos y 
extremos con cinco métodos: (i) la visualización de los datos (o las estadísticas de los datos en bruto); (ii) el cálculo de media $(\bar{x})$ y la desviación estándar (s), después de la eliminación de valores atípicos con el criterio $\bar{x} \pm 2 s$; (iii) la mediana y la diferencia media absoluta (MAD); (iv) el método de Huber; y (v) el método de prueba múltiple del tipo del valor atípico que combina las pruebas de Dixon, Grubbs, asimetría y curtosis en el nivel de confianza del 99\%. Los resultados fueron presentados en la notación científica con la incertidumbre de un dígito significativo. Un estudio comparativo de los cinco métodos estadísticos de tratamientos de datos sugiere que el quinto método proporciona mejores resultados para el análisis estadístico de las mediciones experimentales. Se presenta una evaluación preliminar de la exactitud analítica de los análisis geoquímicos de las aguas geotermales, preparadas con la disolución de 4,585 g de $\mathrm{CaCl}_{2}$ (98.2\%), 16,5 g de $\mathrm{NaCl}(99.9 \%), 3,58 \mathrm{~g}$ de $\mathrm{MgCl}_{2}(99.0 \%), 0,74 \mathrm{~g} \mathrm{de} \mathrm{Na}_{2} \mathrm{SO}_{4}(99,0 \%)$ y $0,95 \mathrm{~g}$ de $\mathrm{KCl}(99,5 \%)$ en 1 litro de solución. Los análisis de $\mathrm{Na}^{+}$y $\mathrm{K}^{+}$son razonablemente precisos, mientras que $\mathrm{Mg}^{2+}$ y $\mathrm{SO}_{4}^{2-}$ tienen una inexactitud alta. La exactitud de $\mathrm{Ca}^{2+}$ y $\mathrm{Cl}^{-}$está en el medio. Un análisis sistemático de los resultados sugiere que la inexactitud en la medición de $\mathrm{Mg}^{2+}, \mathrm{Ca}^{2+}, \mathrm{SO}_{4}^{2-}$ y $\mathrm{Cl}^{-}$está probablemente relacionada con la preparación de la muestra. Las relaciones entre el coeficiente de variación (\% de incertidumbre analítica) y la concentración de cada elemento se derivaron, y posteriormente se utilizaron para la propagación de la incertidumbre en los cálculos geoquímicos de sistemas geotérmicos. El procedimiento de cálculo se ilustra con la propagación de la incertidumbre en el cálculo de la temperatura y la fracción de vapor en el sistema geotérmico del yacimiento de Los Azufres. La incertidumbre en la temperatura estimada es de $\pm 20 \mathrm{~K}$, lo que significa que los cambios en las características de los fluidos del yacimiento geotérmico durante su explotación están en general dentro de la incertidumbre.

Palabras clave: exactitud analítica, DODESSYS, fluidos geotérmicos, comparación entre laboratorios, método estadístico de tratamiento de datos, propagación de incertidumbre.

\section{Introduction}

For long, geoscientists have been greatly concerned with the data quality in rock analysis. Therefore, to evaluate the quality (precision and accuracy) of the chemical analysis of rocks, as early as 1950 , the United States Geological Survey prepared two samples (granite G-1 and diabase $\mathrm{W}-1$ ) and distributed them among several laboratories. The results provided by the participating laboratories were evaluated by Fairbairn et al. (1951). The standard statistical technique was practiced of calculating the sample mean $(\bar{x})$, standard deviation $(s)$, and standard error of the mean $\left(s e_{\bar{x}}\right)$ - the parameters in the category of the outlier-based methods (Verma, 2005). For identifying outlying observations, the measurements outside the two standard deviation of the sample mean $(\bar{x} \pm 2 s)$ were deleted. This simple population-based method has been used later by others for processing the geochemical data for rock reference materials (e.g., Gladney, 1981; Gladney and Roelandts, 1988; Gladney et al., 1990, 1991; Imai et al., 1996). Such fixed multiples of standard deviation methods, such as the two standard deviation method, have been criticised in the literature (Barnett and Lewis, 1994; Verma, 1997, 1998, 2005; Verma and Quiroz-Ruiz, 2006a, b, 2008; Hayes et al., 2007).

Since this early work (Fairbairn et al., 1951), numerous organisations and countries have prepared geochemical reference materials for rocks and a multitude of different statistical procedures have been practiced to process the geochemical data of rock reference materials (e.g., Flaganan, 1967, 1986a, b; Govindaraju and De la Roche, 1977; Steele, 1978; Abbey, 1979a, b; Govindaraju, 1980, 1984, 1994; Potts et al., 1992; Imai et al., 1996). The statisti- cal methods for processing geochemical data have varied from the two standard deviation method and robust methods to more sophisticated outlier-based methods involving a large number of discordancy tests. Thus, although the outlier-based methods had already been used for processing geochemical data for rock reference materials (e.g., Dybczyński et al., 1979; Dybczyński, 1980; Stanley, 1995), Verma (1997) developed a more complete outlier-based method, called the multiple-test method (MTM), which was practiced by several workers for processing the geochemical data of rock reference materials (e.g., Velasco et al., 2000; Guevara et al., 2001; Velasco-Tapia et al., 2001; Marroquín-Guerra et al., 2009; Pandarinath, 2009). The MTM of Verma (1997) has now been significantly improved from the availability of new precise and accurate critical values for a large number of discordancy tests (Verma and Quiroz-Ruiz, 2006a, b, 2008, 2011; Verma et al., 2008a).

In geothermal water research also, the need of quality control and analytical consistency among geochemical laboratories was recognised long ago, when Ellis (1976) conducted the first inter-laboratory comparison of the quality of geochemical analysis in waters, organized by the International Association of Geochemistry and Cosmochemistry (IAGC). Ellis (1976) mentioned that for processing the inter-laboratory data and dealing with outlying observations, he used the recommended practice by the American Society for Testing and Materials. Giggenbach et al. (1992) reinvestigated the scatter in chemical analyses for individual species in the interlaboratory comparison results of Ellis' work. The deficiency in analytical precision and accuracy is one of the most important limitations to develop an understanding 
of chemical processes and the state of water-rock interaction in natural water bodies. Consequently, Giggenbach et al. (1992) emphasized the need for a general improvement and standardization of analytical procedures for each chemical species.

Since then, the International Atomic Energy Agency (IAEA) has conducted various inter-laboratory comparisons for geothermal waters within the framework of the project, "Coordinated Research Program on the Application of Isotope and Geochemical Techniques in Geothermal Exploration" as follows: (i) 22 laboratories from 19 countries (Giggenbach et al., 1992); (ii) 15 laboratories from 7 countries (Gerardo-Abaya et al., 1998); (iii) 26 laboratories from 10 countries (Alvis-Isidro et al., 1999); (iv) 35 laboratories from 16 countries (Alvis-Isidro et al., 2000); (v) 38 laboratories from 23 countries (Alvis-Isidro et al., 2002); and (vi) 31 laboratories from 18 countries (Urbino and Pang, 2004). Verma and co-workers (Verma et al., 2002; Verma, 2004) conducted initial statistical analyses of the results of the inter-laboratory comparisons. The high uncertainty in the analysis of high $\mathrm{SiO}_{2}$ concentration samples was associated with analytical problems (Verma et al., 2002). Similarly, the acid-base titration procedure for the $\mathrm{HCO}_{3}$ - determination was shown to be conceptually incorrect (Verma, 2004).

The geothermal systems studied in different parts of the world are generally different, so the reproducible and accurate analytical measurements in laboratories around the world are fundamental in formulating principles and laws on the basis of comparative evidence obtained from the studies of various similar systems. For example, the cation exchange geothermometers (e.g., Na-K, Na-K-Ca, etc.) are empirical relations derived from the behavior of analytical measurements of geothermal waters from the geothermal fields all over the world (Fournier and Truesdell, 1973; Verma and Santoyo, 1997; Verma et al., 2008b), although their equations have no thermodynamic validation (Verma, 2002) and even no physical unit balance (Verma, 2010).

The analyses of the geothermal waters were performed by many laboratories. Thus, the analytical quality control parameters of each laboratory, such as the instrument detection limits, the method detection limits, and the analytical accuracy and uncertainty in the measurements, are crucial for the derivation of these types of conclusions (i.e., the existence of cation exchange of geothermometers).

Verma (2008a) compiled the literature on the worldwide progress to create reference materials (standards) for each chemical species and to calibrate the analytical technique with such materials in order to obtain a consistency in the analytical database on the natural geological systems. The chemical and isotopic calculations \begin{tabular}{lcl}
\hline Code & Labs & Characteristics \\
\hline IAEA01 & 22 & $\begin{array}{l}\text { Sample } 001 \text { from Giggenbach } \text { et al. }(1992) . \text { A clear colorless } \\
\text { boiling }\left(97.5^{\circ} \mathrm{C}\right) \text { spring at Waikite. The sample was collected }\end{array}$
\end{tabular} on 31-12-1985.

IAEA02 22 Sample 002 from Giggenbach et al. (1992). Separated water from the weir box of well WK66 at Wairakei collected on 30-12-1985.

IAEA03 15 Sample RASINT 1 from Gerardo-Abaya et al. (1998). Cold neutral $\mathrm{pH}$ bicarbonate, low $\mathrm{Cl}^{-}$spring water from China, collected by the East China Geological Institute.

IAEA04 15 Sample RASINT 2 from Gerardo-Abaya et al. (1998). High temperature neutral $\mathrm{pH}, \mathrm{Cl}^{-}$geothermal well water from Palinpinon geothermal field, Philippines collected by PNOCEDC.

IAEA05 26 Sample WILC-01 from Alvis-Isidro et al. (1999). High salinity water from a boiling spring $\left(94^{\circ} \mathrm{C}\right)$ at Suoh, Lampung in South Sumatera, Indonesia collected by CAIR-BATAN.

IAEA06 26 Sample WILC-02 from Alvis-Isidro et al. (1999). Water from a low salinity warm spring in San Kamphaeng, Thailand collected by the Department of Geological Sciences, Chiang Mai University and the Electricity Generating Authority of Thailand.

IAEA07 35 Sample IGWC-01 from Alvis-Isidro et al. (2000). Low salinity water from a cold spring $\left(26^{\circ} \mathrm{C}\right)$ situated in a geothermal area in Southern Luzon, Philippines collected by PNOCEDC.

IAEA08 35 Sample IGWC-02 from Alvis-Isidro et al. (2000). High salinity geothermal water from a high-temperature production well at Leyte, Philippines collected by PNOC-EDC.

IAEA09 38 Sample GWIN-01 from Alvis-Isidro et al. (2002). High salinity water form an injection pipeline in the PGI-Tiwi geothermal field, Philippines collected by PNOC-EDC.

IAEA10 38 Sample GWIN-02 from Alvis-Isidro et al. (2002).Low salinity water from a cold spring $\left(26^{\circ} \mathrm{C}\right)$ in the province of Laguna, Philippines collected by PNOC-EDC.

IAEA11 38 Sample GWIN-03 from Alvis-Isidro et al. (2002). Medium salinity water from a warm spring $\left(60^{\circ} \mathrm{C}\right)$ in Bacon-Manito geothermal field, Philippines collected by PNOC-EDC.

IAEA12 31 Sample GW-03-01 from Urbino and Pang (2004). A mixer of $44 \%$ GW-03-02 and 56\% GW-03-03.

IAEA13 31 Sample GW-03-02 from Urbino and Pang (2004). Medium salinity water from a geothermal well in the Leyte geothermal field, Philippines collected by PNOC-EDC.

IAEA14 5 Sample GW-03-03 from Urbino and Pang (2004). Solution prepared by PNOC-EDU with dissolving $4.585 \mathrm{~g} \mathrm{CaCl}_{2}$ (98.2\%), $16.5 \mathrm{~g} \mathrm{NaCl}(99.9 \%), 3.58 \mathrm{~g} \mathrm{MgCl}_{2}(99.0 \%), 0.74$ $\mathrm{g} \mathrm{Na}_{2} \mathrm{SO}_{4}(99.0 \%)$ and $0.95 \mathrm{~g} \mathrm{KCl}(99.5 \%)$ in 1 liter of solution.

Table 1.- Characteristics of samples distributed during the IAEA interlaboratory comparison programs, modified after Verma (2008a).

Tabla 1.- Características de las muestras distribuidas en los programas de comparación inter-laboratorios del OIEA, modificado de Verma (2008a).

in aquatic systems are complementary to understanding natural processes in geological systems (Parr and Clements, 1991; Araguás and Rozanski, 1995; Lippmann et al., 1999; Verma, 2004).

Because there are several different statistical methods available for processing experimental data, in the present article the geochemical data from the IAEA inter-laboratory comparisons of geothermal waters were compiled and used for evaluating the merits and demerits of five data treatment approaches. The relations between the co- 
efficient of variation (here termed as \% analytical uncertainty) and the concentration of each chemical species are derived. These relations were used for the propagation of uncertainty in the geochemical calculations to predict the reservoir characteristics of the Los Azufres geothermal system.

\section{The IAEA inter-laboratory comparisons}

The characteristics of samples distributed under the IAEA inter-laboratory calibration programs are presented in Table 1. Verma (2008a) described briefly the basic procedure of the inter-laboratory comparisons. The natural water samples do not permit computation of analytical errors since the true values of their chemical parameters are unknown. Therefore, the IAEA prepared a synthetic sample (IAEA14) of known chemical composition by dissolving analytical grade chemical reagents in distilled water. The concentration of each chemical species in the solution IAEA14 was calculated from the amount of dissolved reagents. These values of concentration are considered to be conventional "true" values. Therefore, the IAEA14 sample is used for understanding analytical errors in the analyses of different species, although the sample was analyzed by only five laboratories. Similarly, the IAEA12 sample was also used to understand the bias in the analytical measurements as it is a mixture of IAEA13 and IAEA14. The proportion of both IAEA13 and IAEA14 samples in the preparation of IAEA12 is given in Table 1.

\section{Statistical data treatment procedures}

The basic assumption in the analytical data analysis is that a statistical sample is a random selection of certain values from the population, which represents an unbiased representative statistical sample of the whole population (Barnett and Lewis, 1994). The statistical data treatment methods provide a systematic procedure to obtain an estimate of the parameters of population distribution (mean $\mu$, and standard deviation $\sigma$ ) from the parameters of sample distribution (mean $\bar{x}$ and standard deviation $s$ ).

The uncertainty of measurements together with the instrument detection limit (IDL) and the method detection limit (MDL) in the geochemical analysis of geothermal waters is, generally, not reported in the scientific literature. The IAEA inter-laboratory comparisons were conducted between well-established laboratories in the geothermal industry. In the absence of laboratory data quality parameters (i.e. IDL, MDL, uncertainty, etc.) the uncertainty of measurements is considered as the statistical fluctuation (i.e. the uncertainty equals to $\pm 1 s$; WDNR, 1996).
The basic aspects of statistical data treatment and its implementation in the experimental sciences are illustrated with an example, the measurement of length (say $20.0 \mathrm{~cm}$ ) of a pencil with a ruler. The value of IDL as well as MDL is $\pm 0.05 \mathrm{~cm}$. The analytical uncertainty is \pm 0.1 $\mathrm{cm}$ (i.e. 2 times of MDL). The value of length is reported as $20.0 \pm 0.1 \mathrm{~cm}$. Thus the length of the pencil is within 19.9 and $20.1 \mathrm{~cm}$ with $68.3 \%$ confidence. For illustrating purposes, the standard deviation of the measurements is considered as $0.1 \mathrm{~cm}$. If someone measured incorrectly the length of the pencil as $10.0 \mathrm{~cm}$, we immediately remove this value.

Mathematically, the probability distribution of the measurement of a pencil length is normal (Gaussian). So, any value of the pencil length from $-\infty$ to $+\infty \mathrm{cm}$ is statistically possible. Thus the length $10.0 \mathrm{~cm}$ is also a part of the distribution; indeed, the probability of its occurrence is infinitesimally small. Statistically, there is $99.7 \%$ confidence interval that the values will be within $\bar{x} \pm 3 \mathrm{~s}$. For the above example, the length of the pencil will be within 19.7 and 20.3 with $99.7 \%$ confidence. Thus the removal of the value $10.0 \mathrm{~cm}$ will not alter the result even in statistics. There is a problem in the above example if the length (as $20.0 \mathrm{~cm}$ ) of the pencil is unknown; however, there is more probability that the measured values fall near the mean of the dataset. The recent statistical data treatment methods dealing with the subject have an emphasis on the detection and removal of outliers and on robust statistical approaches. The extremum and outlier have different meanings, but it is difficult to distinguish between them during the statistical data analysis. In the above example the value $10.0 \mathrm{~cm}$ is an extremum of the same probability distribution, if most of the measurements are around $20.0 \mathrm{~cm}$. The $10.0 \mathrm{~cm}$ length can be predicted as outlier if its probability of measurement is also known. In other words, a necessary condition to identify the outlier of a probability distribution is to know both value and its occurrence probability of the parameter.

\subsection{Data visualization method}

The data visualization (or raw data statistics) method for the statistical analysis of experimental measurements is in use since the beginning of the development of systematic sciences. It consists of calculating mean and standard deviation of the dataset after removing the extremum values associated with some errors in measurement, misprints, etc. The first step of statistical analysis of a dataset is to draw a histogram grouping the values in certain range. The histogram provides the information about the probability distribution of the dataset. In geosciences, the limited number of analytical measure- 


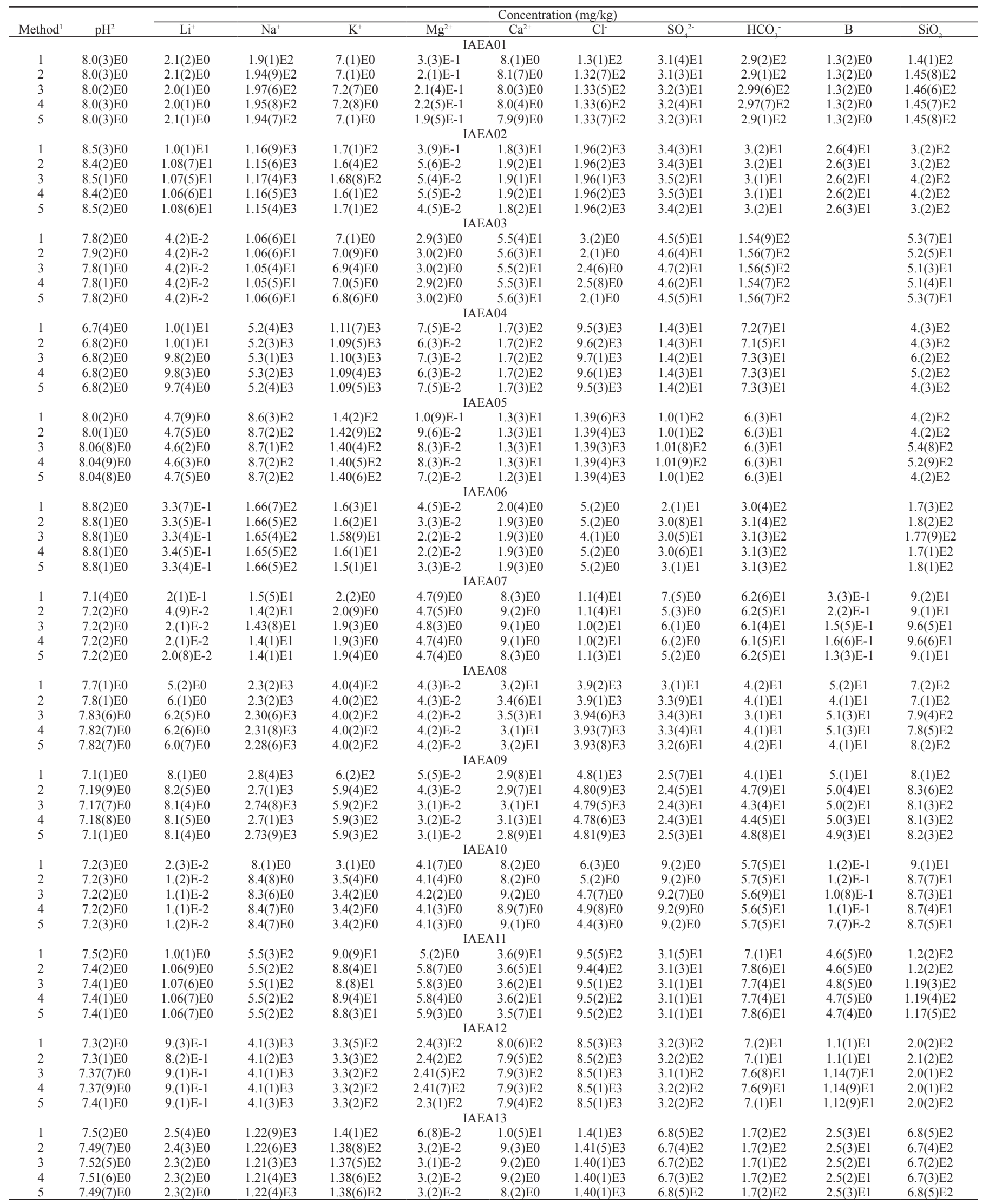

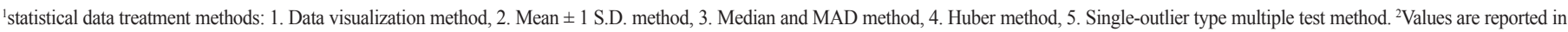

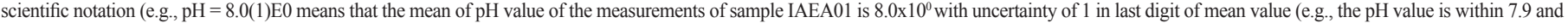
8.1). There are two significant digits.

Table 2.- A comparative summary of statistical analyses of chemical analyses of water sample using the five statistical data treatment methods.

Tabla 2.- Resumen comparativo de los análisis estadísticos de los análisis químicos de muestras de agua con los cinco métodos de tratamiento de los datos estadísticos considerados en este estudio. 

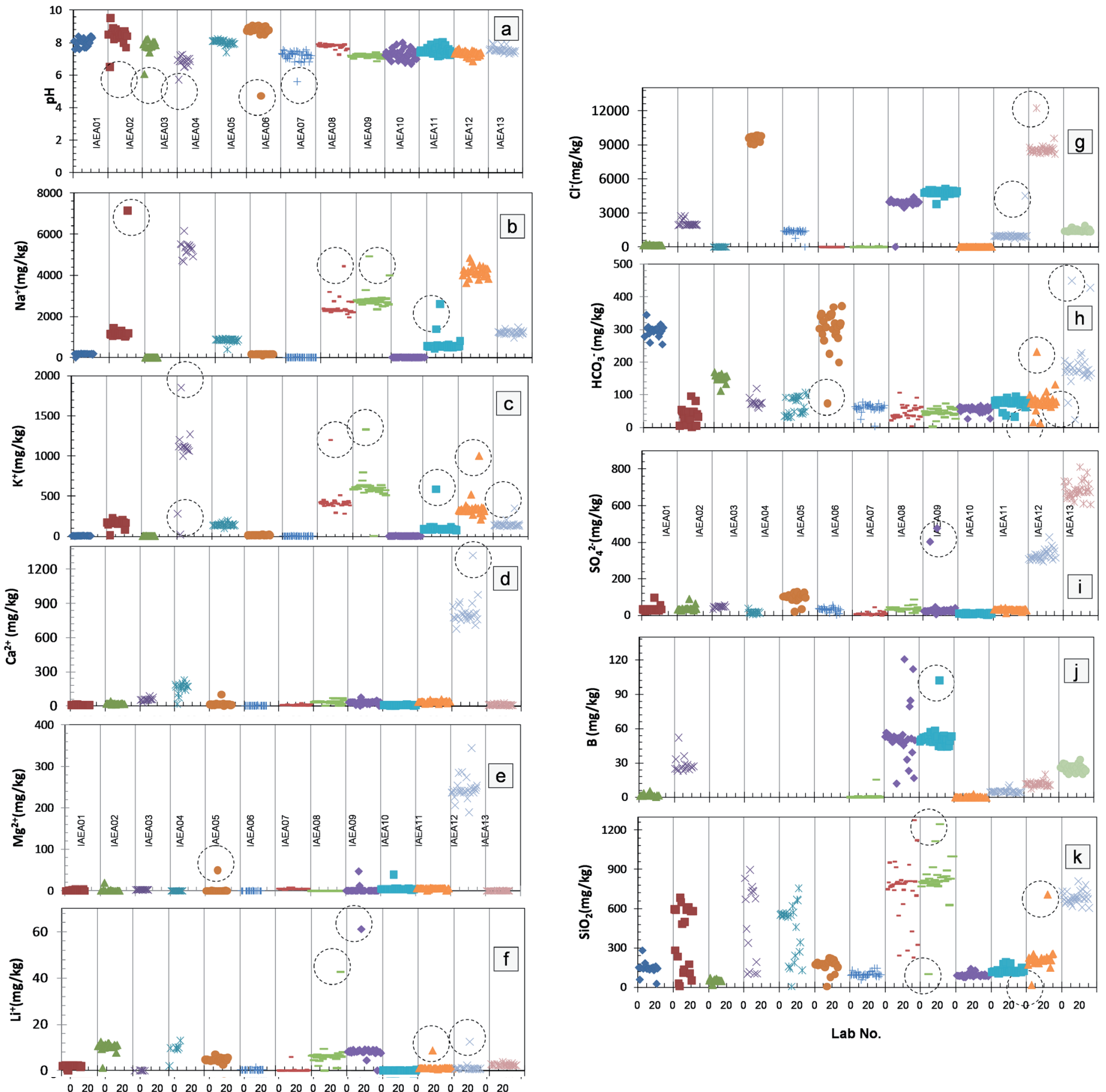

Lab No.

Lab No.

Fig. 1.- Relation between the laboratory number and the analysis of different parameters, analyzed in the thirteen samples as part of the IAEA inter-laboratory comparison program during 1992 and 2004. The extremums obtained with data visualization approach are marked with dashed circles. In the case of large spread in the values (e.g., $\mathrm{HCO}_{3}^{-}$and $\mathrm{SiO}_{2}$ ), the identification of outliers is difficult with this approach.

Fig. 1.- Relación entre el número de laboratorio y el análisis de diferentes parámetros, analizados en las trece muestras como parte del programa de comparación entre laboratorios del OIEA entre los años 1992 y 2004. Los extremos obtenidos con el enfoque de visualización de datos están marcados con círculos con trazos discontinuos. En el caso de mayores dispersiones entre los valores (por ejemplo, $\mathrm{HCO}_{3}^{-}$y $\mathrm{SiO}_{2}$ ), la identificación de los valores extremos es difícil con este procedimiento.

ments does not provide a meaningful histogram. So, the consideration of a normal probability distribution curve is associated with our knowledge of the analytical tech- nique itself. In a perfect normal probability distribution the mean, median and mode of experimental dataset coincide and the results are reported as $\bar{x} \pm 1 s$ with $68.3 \%$ 
confidence interval.

Figure 1 shows the results of all the IAEA inter-laboratory comparisons of geothermal waters. For example, the $\mathrm{Li}^{+}$concentration of IAEA12 was reported by 22 laboratories. 21 values were within the range 0.56 to $2.30 \mathrm{mg} /$ $\mathrm{kg}$, while one value was $12.54 \mathrm{mg} / \mathrm{kg}$. It is clear that the value $12.54 \mathrm{mg} / \mathrm{kg}$ is associated with some typing mistake when passing the data from one person to another. The mean and standard deviation of the dataset after excluding the value $12.54 \mathrm{mg} / \mathrm{kg}$ are 0.96 and $0.34 \mathrm{mg} / \mathrm{kg}$, respectively. The $\mathrm{Li}^{+}$concentration of IAEA12 is $1.0 \pm 0.3$ $\mathrm{mg} / \mathrm{kg}$, considering the correct significant figures. Including the extremum value (12.54 ppm) the mean and standard deviation change to 1.46 and $2.44 \mathrm{mg} / \mathrm{kg}$ respectively, and the $\mathrm{Li}^{+}$concentration of IAEA12 is $1 \pm 2 \mathrm{mg} / \mathrm{kg}$.

The scientific notation avoids some confusion about the number of significant figures in a value (Harvey, 2000). For example, the two values of concentration in the scientific notation are here written as 1.0(3)E0 (i.e. 1.0x10 with uncertainty of 3 in last significant digit " 0 ") and 1(2) E0 mg/kg, respectively. Thus the first value has 2 significant digits, while the second value has only 1 significant digit.

In the data visualization method (method 1) it is assumed that all the analytical techniques are appropriate and there is more probability that the measured values fall near the mean value of the measured parameter. If this assumption is not valid, there is no justification for performing any statistical analysis of the dataset. Thus in the above example the $\mathrm{Li}^{+}$concentration of IAEA12 is $1.0(3) \mathrm{E} 0 \mathrm{mg} / \mathrm{kg}$, which is obtained after removal of $12.54 \mathrm{mg} / \mathrm{kg}$ value form the dataset. It is not always easy to identify the extremum values by seeing the dataset. The plotting of data in xy-plot helps the identification of extremums (Fig. 1). The outliers (or extremums) are marked with dashed circles.

\subsection{Mean \pm 1 S.D. method}

In the method 1, it is not always feasible to detect extremums (outliers) with certainty when there is a large spread in the measured values (e.g., $\mathrm{HCO}_{3}^{-}$and $\mathrm{SiO}_{2}$ analyses in Fig. 1). Similarly, the process of detection and removal of extremums is affected by human factors in the above method.

The confidence intervals are $68.3 \%, 95.4 \%$ and $99.7 \%$ in reporting the values in confidence levels of $\mu \pm 1 \sigma, \mu \pm 2 \sigma$, and $\mu \pm 3 \sigma$, respectively, where $\mu$ is the population mean and $\sigma$ is the population standard deviation. Our objective is to get $\bar{x}$ and $s$ close to $\mu$ and $\sigma$, respectively. The extremums affect highly the values of $\bar{x}$ and $s$, so every statistical method consists of reducing the influence of extremums. This method 2 contemplates the computation of

\begin{tabular}{|c|c|c|c|c|c|c|c|}
\hline \multirow[t]{2}{*}{ Species } & \multicolumn{2}{|c|}{ True } & \multicolumn{2}{|c|}{ Measured } & \multirow{2}{*}{$\begin{array}{c}\% \\
\text { Error }^{(e)}\end{array}$} & \multirow[t]{2}{*}{ C.V. ${ }^{(f)}$} & \multirow{2}{*}{$\begin{array}{c}\text { Measured } \\
\text { data report }\end{array}$} \\
\hline & Value $^{(a)}$ & S.D. ${ }^{(b)}$ & Value $^{(\mathrm{c})}$ & S.D. ${ }^{(\mathrm{d})}$ & & & \\
\hline $\mathrm{Na}^{+}$ & 6721.3 & 4.4 & 6395 & 246 & -5 & 4 & $6.4(2) \mathrm{E} 3$ \\
\hline $\mathrm{K}^{+}$ & 495.7 & 1.2 & 490 & 21 & -1 & 4 & 4.9(2)E2 \\
\hline $\mathrm{Ca}^{2+}$ & 1626.0 & 14.9 & 1410 & 74 & -13 & 5 & $1.41(7) \mathrm{E} 3$ \\
\hline $\mathrm{Mg}^{2+}$ & 904.7 & 4.6 & 419 & 11 & -54 & 3 & 4.2(1)E2 \\
\hline $\mathrm{Cl}^{-}$ & 15964.8 & 45.8 & 13957 & 306 & -13 & 3 & $1.40(3) \mathrm{E} 4$ \\
\hline $\mathrm{SO}_{4}^{-}$ & 495.4 & 2.5 & 49 & 6 & -92 & 12 & 4.9(6)E1 \\
\hline \multicolumn{8}{|c|}{$\begin{array}{l}\text { (a) The concentration of each species is calculated on the basis of the dissolved amount and } \\
\text { is considered as the conventional true value, according to the ISO definition. }\end{array}$} \\
\hline \multicolumn{8}{|c|}{$\begin{array}{l}\text { (b) The standard deviation ( } 1 \text { S.D.) is calculated from half of the quoted impurity in the } \\
\text { chemical reagents. The values are relatively small and neglected for further calculations. } \\
\text { (c) Average (mean) of all the values reported by each laboratory for respective chemical } \\
\text { parameter. }\end{array}$} \\
\hline \multicolumn{8}{|c|}{ (d) Standard deviation in the values reported by the participating laboratories. } \\
\hline $\begin{array}{l}\text { (e) } \% \text { analy } \\
\text { (f) The co } \\
\text { (g) The va }\end{array}$ & ytical error is & defined as & $\%$ Error $=$ & $\frac{\text { leasurea }}{T r}$ & Le value & value $\times 10$ & . \\
\hline
\end{tabular}

Table 3.- Comparison between the conventional true and measured values (in $\mathrm{mg} / \mathrm{kg}$ ) for IAEA14, prepared by dissolving $4.585 \mathrm{~g} \mathrm{CaCl}_{2}$ (98.2\%), $16.5 \mathrm{~g} \mathrm{NaCl}(99.9 \%), 3.58 \mathrm{~g} \mathrm{MgCl}_{2}$ (99.0\%), $0.74 \mathrm{~g} \mathrm{Na}_{2} \mathrm{SO}_{4}$ $(99.0 \%)$ and $0.95 \mathrm{~g} \mathrm{KCl}(99.5 \%)$ in 1 liter of solution (modified after Verma, 2008a).

Tabla 3.- Comparación entre los valores aceptados como verdaderos por convención y los valores medidos (en $\mathrm{mg} / \mathrm{kg}$ ) para IAEA14, preparada por disolución de $4.585 \mathrm{~g} \mathrm{CaCl}_{2}(98.2 \%), 16.5 \mathrm{~g} \mathrm{NaCl}$ (99.9\%), $3.58 \mathrm{~g} \mathrm{MgCl}_{2}(99.0 \%), 0.74 \mathrm{~g} \mathrm{Na}_{2} \mathrm{SO}_{4}(99.0 \%)$ and $0.95 \mathrm{~g}$ $\mathrm{KCl}(99.5 \%)$ en un litro de solución (modificado de Verma, 2008a).

mean and standard deviation after removal of values out of $\bar{x} \pm 2 s$, where $\bar{x}$ and $s$ are the mean and standard deviation of method 1, respectively. The final results of method 2 as $\bar{x} \pm 1 s$ have $65.2 \%$ confidence interval, instead of $68.3 \%$.

\subsection{Median and Median Absolute Deviation (MAD) method}

The robust statistical methods are resistant to outliers in the dataset. AMC (2001) described the procedure to perform the data statistics using this method in two steps. (i) Median of the dataset: It is considered that the median is a representative of the mean of the dataset. (ii) Median Absolute Deviation (MAD): Let the values of a dataset are $\mathrm{x}_{1}, \mathrm{x}_{2}, \mathrm{x}_{3}, \ldots \mathrm{x}_{\mathrm{n}}$, and their median is $\mathrm{M}$. The absolute difference between the values and the median is calculated as $\left|x_{i}-M\right|$. Then the MAD is defined as the median of the absolute difference values. The MAD is considered as uncertainty in $\mathrm{M}$. The results are reported as $\mathrm{M} \pm \mathrm{MAD}$ instead of $\bar{x} \pm 1 \mathrm{~s}$. There is no removal of outliers in this method; however, there is no proof of the mathematical equivalence between $\mathrm{M} \pm \mathrm{MAD}$ and $\bar{x} \pm 1 s$.

\subsection{Huber method}

The Huber's method makes more use of the information provided by the dataset (AMC, 2001). The original 


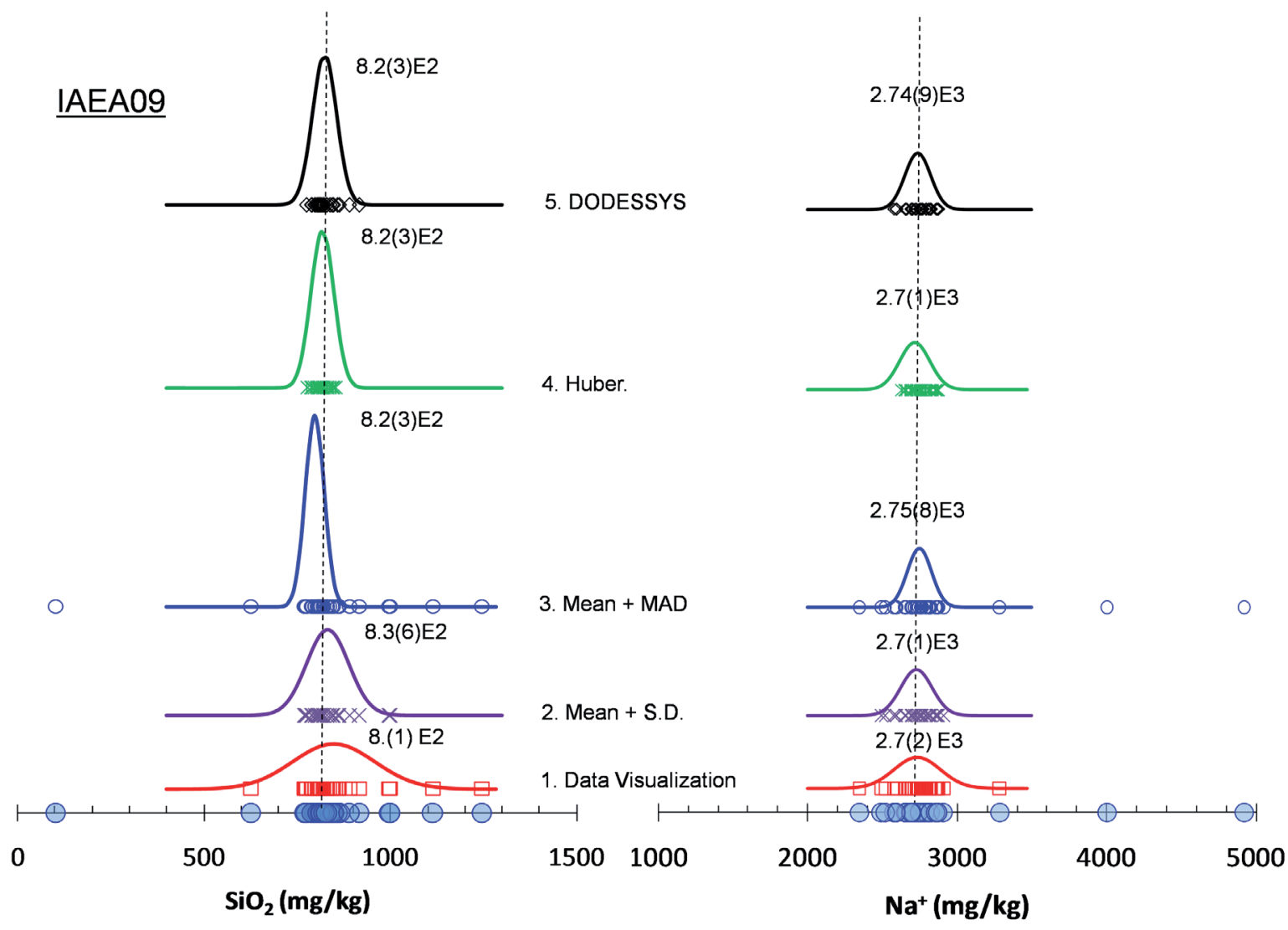

Fig. 2.- Comparison of the evaluation of mean and standard deviation of the analyses of $\mathrm{Na}^{+}$and $\mathrm{SiO}_{2}$ in IAEA09 water sample with five statistical data treatment methods. The original values are shown with filled circles on the concentration axis. It also shows the probability distribution curve for each method together with the data values considered in the respective method. The mean and standard deviation values are depicted in scientific notation. For example, according to the DODESSYS method the $\mathrm{SiO}_{2}$ concentration is 8.2(3)E2, which is $8.2 \times 10^{2}$ with uncertainty of 3 (i.e. 1 standard deviation) in the last significant digit, "2" (i.e. 790 to $850 \mathrm{mg} / \mathrm{kg}$ ).

Fig. 2.- Comparación de la evaluación de la media y desviación estándar de los análisis de $\mathrm{Na}^{+}$y $\mathrm{SiO}_{2}$ en la muestra de agua IAEA09 con cinco métodos estadísticos de tratamiento de datos. Los valores originales se muestran con círculos llenos en el eje de concentración. También se muestra la curva de distribución de probabilidad para cada método, junto con los valores de los datos considerados en el método respectivo. Los valores promedio y de desviación estándar se muestran en notación científica. Por ejemplo, según el método DODESSYS la concentración de $\mathrm{SiO}_{2}$ es de 8.2 (3) E2, que es $8.2 \times 10^{2}$ con la incertidumbre de 3 (es decir, 1 desviación estándar) en el último dígito significativo, "2" (es decir, 790 a $850 \mathrm{mg} / \mathrm{kg}$ ).

data are transformed by a process called winsorisation. Assume that we have initial estimates of $\mathrm{M}$ and MAD. If a value falls above $\mathrm{M}+1.5 \mathrm{MAD}$, it is changed to $\mathrm{M}+1.5$ MAD. Similarly, if a value falls below M-1.5 MAD, it is changed to M-1.5 MAD. Otherwise, the value remains unchanged. Then the mean and standard deviation of the original data are considered as $\bar{x}$ and $1.13 s$, where $\bar{x}$ and $s$ are the mean and standard deviation of improved data, respectively. The method adds weight to the central values by removing the extremums on the basis of above criteria. Thus the method is in-between the methods 2 and 3 .

\subsection{Single-outlier type multiple test method}

The removal of outliers (extremums) in the methods 2 and 4 is quite abrupt. For example, there may be two values in a dataset such that one just satisfies the condition $\bar{x} \pm 2 s$, whereas the other value is just outside the condition. So, we have to remove one and consider the other value in the statistical data analysis. In practice both have the same influence on the results of the statistical data analysis. To tackle these situations, the Dixon and Grubbs test method is useful. Verma et al. (2008a) simulated new critical values for these and other discordancy tests and implemented the modified version of Dixon and Grubbs test method in a computer program, DODESSYS (Discordant Outlier DEtection and Separation SYStem; Verma and Díaz-González, 2012) and named as the single-outlier type multiple-test method involving Dixon, Grubbs, skewness and kurtosis tests at 99\% confidence level, initially proposed and used by Verma (1997) for processing inter-laboratory data on geochemical rock ref- 


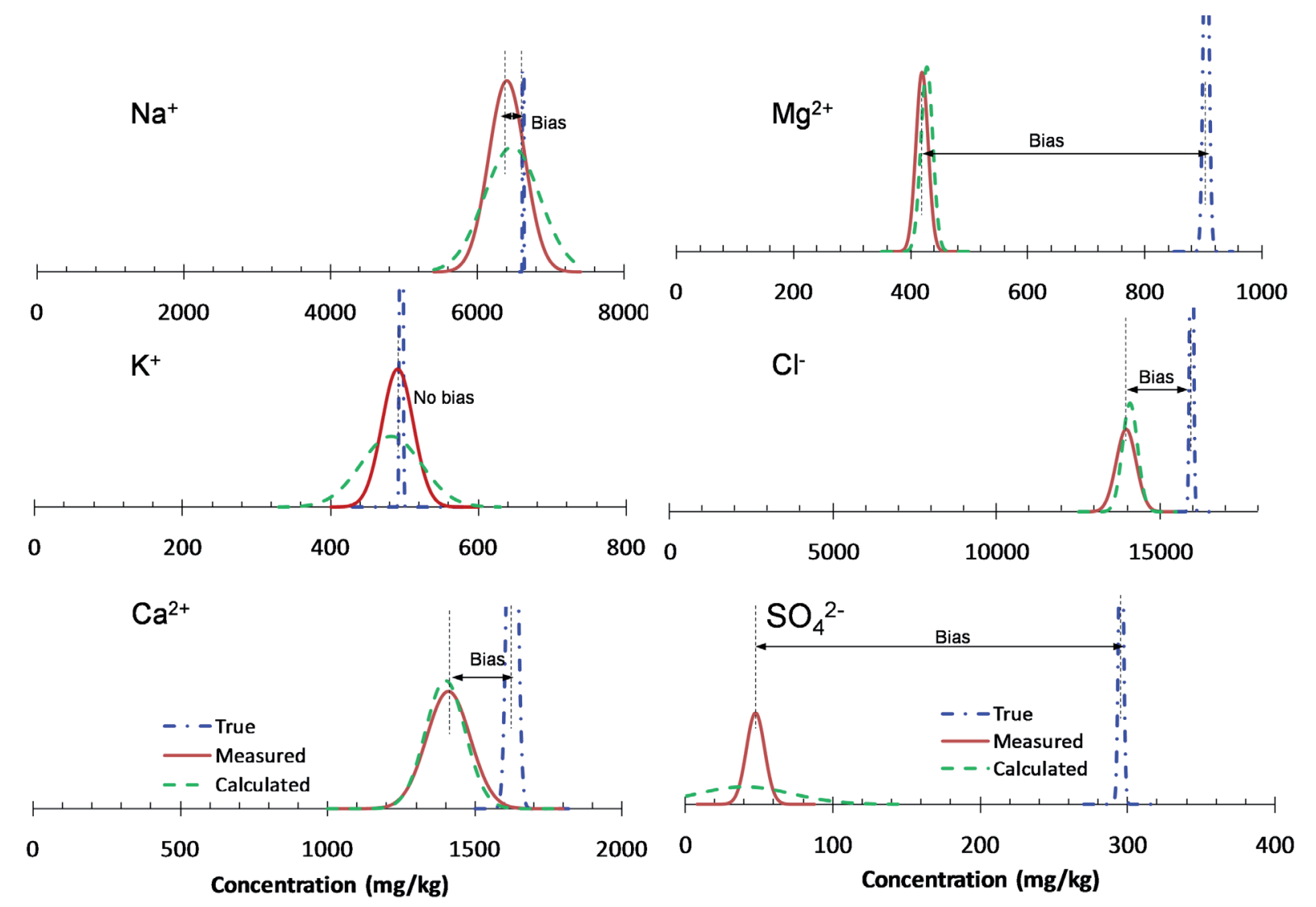

Fig. 3.- Accuracy evaluation of the geochemical analysis in water samples. The sample IAEA14 was prepared by dissolving $4.585 \mathrm{~g}$ CaCl (98.2\%), $16.5 \mathrm{~g} \mathrm{NaCl}$ (99.9\%), $3.58 \mathrm{~g} \mathrm{MgCl}_{2}$ (99.0\%), $0.74 \mathrm{~g} \mathrm{Na}_{2} \mathrm{SO}_{4}(99.0 \%)$ and $0.95 \mathrm{~g} \mathrm{KCl}(99.5 \%)$ in 1 liter of solution. The IAEA14 sample was analyzed by five laboratories. Its statistics is shown as measured curve. The calculated curves represent the statistics of IAEA14, obtained by subtracting the contribution of IAEA13 from IAEA12.

Fig. 3.- Evaluación de la precisión de los análisis geoquímicos de muestras de agua. La muestra IAEA14 se preparó disolviendo $4.585 \mathrm{~g}$ de $\mathrm{CaCl}_{2}$ (98.2\%), $16.5 \mathrm{~g}$ de $\mathrm{NaCl}$ (99.9\%), $3.58 \mathrm{~g}$ de $\mathrm{MgCl}_{2}$ (99.0\%), $0.74 \mathrm{~g} \mathrm{Na}_{2} \mathrm{SO}_{4}(99.0 \%)$ y $0.95 \mathrm{~g}$ de $\mathrm{KCl}$ (99.5\%) en 1 litro de solución. La muestra IAEA14 fue analizada por cinco laboratorios. Su estadística se muestra como la curva de medición. Las curvas calculadas representan las estadísticas de IAEA14, obtenidas restando la contribución de IAEA13 de IAEA12.

erence materials. The evaluation of the relative efficiency of these single-outlier tests by Verma et al. (2009) showed that the Dixon tests are less efficient than the other three types. In this method, the process of removal of outliers is iterated on the remaining dataset till there is no discordant outlier. In fact, in the output from DODESSYS the outlying observations are separated in a different data file, which could be used for further treatment and understanding of the possible causes of discordancy.

\subsection{Comparison among statistical data treatment methods}

Figure 2 presents a diagram to illustrate the comparative evaluation of $\mathrm{SiO}_{2}$ and $\mathrm{Na}^{+}$concentration of IAEA09 with the five statistical data treatment methods. A similar methodology may be applied to any chemical parameter of any sample. The original untreated concentration values are shown on the concentration axis with filled cir- cles. Similarly, the treated values of $\mathrm{SiO}_{2}$ and $\mathrm{Na}^{+}$with their respective probability distribution curves for all the five statistical methods are also shown in the figure.

For example, the concentration of $\mathrm{SiO}_{2}$ (in $\mathrm{mg} / \mathrm{kg}$ ) for all the methods are 8(1)E2, 8.3(6)E2, 8.1(3)E2, 8.1(3)E2, and 8.2(3)E2, respectively. The confidence levels for the third and fourth methods (MAD and Huber methods) are not defined; however, the first, second and fifth methods have the confidence level values, 100, 95 and $99 \%$, respectively. For these three methods, the concentrations of $\mathrm{SiO}$ lie in the ranges 700 to 900,770 to 890 , and 790 to $850 \mathrm{mg} / \mathrm{kg}$, respectively. Thus the fifth method DODESSYS provides slightly better precision.

There is one more point to be emphasized. There is removal of more data points in DODESSYS; however, it has higher confidence level (i.e. 99\%) than that for the mean \pm 1 S.D. method (95\%). It is associated with the basic assumption of the methods. As mentioned earlier, the 

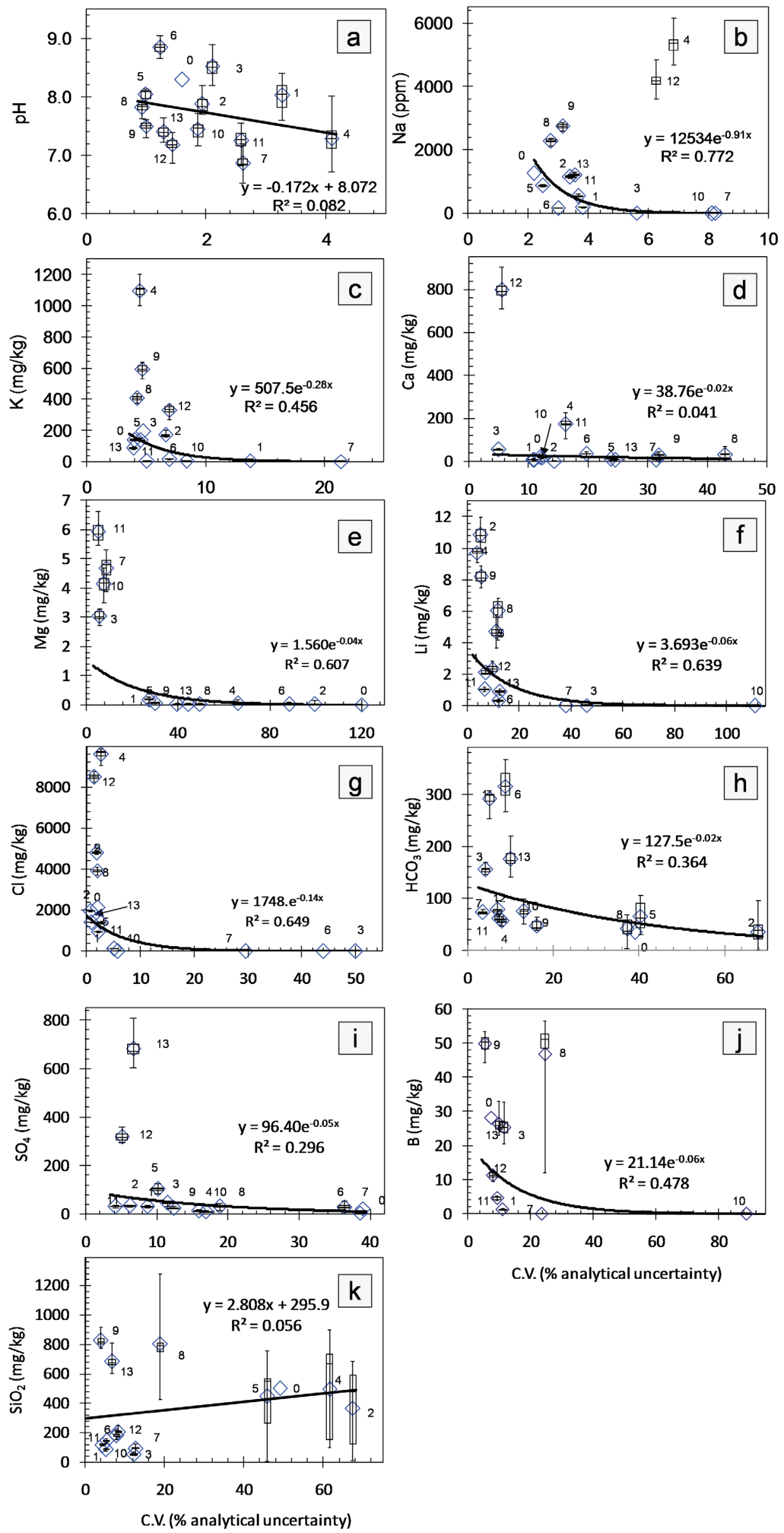

Fig. 4.- Whisker plots for each parameter of the analytical data reported by the participating laboratories in the intercomparison programs. The mean value of each dataset is shown by rhombus. The points 1 to 13 represent samples IAEA1 to IAEA13, respectively. The point 0 is the statistics of a geothermal water sample taken from Ellis (1976). The data values of each sample were treated following the fifth method by the computer program DODESSYS (Verma and Díaz-González, 2012).

Fig. 4.- Gráficas de caja y bigotes para cada parámetro de los datos analíticos presentados por los laboratorios participantes en los programas de inter-comparación. El valor medio de cada conjunto de datos se muestra por rombo. Los puntos 1 a 13 representan las muestras IAEA1 a IAEA13, respectivamente. El punto 0 es la estadística de una muestra de agua geotérmica tomada de Ellis (1976). Los valores de cada muestra fueron tratados por el quinto método con el programa informático DODESSYS (Verma y Díaz-González, 2012). 


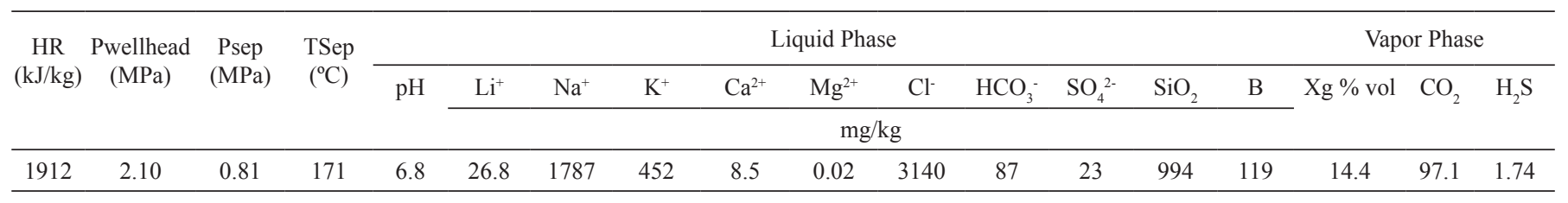

Table 4.- Chemical composition of the well AZ-5 from Los Azufres geothermal field (Tello, 2005).

Tabla 4.- Composición química del pozo Az-05 del campo geotérmico Los Azufres (Tello, 2005).

basic assumption is that the sample distribution is a random selection from the population distribution and also represents the population distribution. The selection may be justified, but the representation depends on the selection. If the selected values are not near the mean value, the sample distribution may not represent the population distribution. The fifth method evaluates the behavior of each individual value for the probability distribution function. Thus it has a mathematical basis for the statistical analysis and will be considered here for the propagation of analytical uncertainty in the geochemical calculation for a geothermal system.

\section{Analytical Data Quality}

There are two aspects to be taken into account during performing analytical analyses: reproducibility and accuracy. The statistical methods do not provide clues on the accuracy of the analysis. To improve the analytical quality of the participating laboratories it is necessary to run some common commercial reference materials in all the laboratories together with the geothermal water samples, as has been established in case of stable isotope mass spectrometry by the IAEA (Lippmann et al., 1999).

The sample IAEA14 was prepared by Urbino and Pang (2004) by dissolving commercial reagents (i.e. producing a solution of known chemical composition); therefore, the calculated value of each chemical parameter for IAEA14 was considered to be a conventional true value. Table 3 presents a comparison between conventional true and measured values of $\mathrm{Na}^{+}, \mathrm{K}^{+}, \mathrm{Ca}^{2+}, \mathrm{Mg}^{2+}$, $\mathrm{Cl}^{-}$and $\mathrm{SO}_{4}^{2-}$. Figure 3 shows the probability distribution curve for the conventional true, measured and calculated values of $\mathrm{Na}^{+}, \mathrm{K}^{+}, \mathrm{Ca}^{2+}, \mathrm{Mg}^{2+}, \mathrm{Cl}^{-}$and $\mathrm{SO}_{4}^{2-}$. The sample IAEA14 was measured by five reference laboratories (Urbino and Pang, 2004). The statistics of each parameter is shown as the measured curve in Figure 3. The measured values of species $\mathrm{Na}^{+}, \mathrm{K}^{+}, \mathrm{Ca}^{2+}, \mathrm{Mg}^{2+}, \mathrm{Cl}^{-}$and $\mathrm{SO}_{4}^{2-}$ have an analytical error of $-5,-1,-13,-54,-12.6$ and -92 $\%$, respectively (Table 3 ). The coefficients of variation for the respective species are 4, 4, 5, 3, 3 and 12 (Table $3)$. Thus the percentage of uncertainty of measurements (i.e. C.V.) is approximately similar to the analytical error for $\mathrm{Na}^{+}$and $\mathrm{K}^{+}$, whereas the analytical error is relatively higher than the uncertainty for $\mathrm{Ca}^{2+}, \mathrm{Mg}^{2+}, \mathrm{Cl}^{-}$and $\mathrm{SO}_{4}^{2-}$. The sample IAEA12 is a mixture of IAEA13 and IAEA14. The concentration of IAEA14 is calculated by subtracting the proportion of IAEA13 from IAEA12. The statistics of these data is shown as the calculated curve in Figure 3. The measured and calculated curves coincide except for the higher spread in the calculated curves. It is due to the propagation of errors (uncertainties) during the calculations. It can be concluded that each laboratory has good reproducibility; however, there is some systematic error. The analytical techniques for $\mathrm{Na}^{+}$and $\mathrm{K}^{+}$analyses are acceptable since the uncertainty of measurements is approximately similar to analytical error, while there is need of revision for the analytical techniques of $\mathrm{Ca}^{2+}$, $\mathrm{Mg}^{2+}, \mathrm{Cl}^{-}$and $\mathrm{SO}_{4}^{2-}$ since there is also bias in the measured values of these parameters. Secondly, it suggests that the bias in the measured values of $\mathrm{Ca}^{2+}, \mathrm{Mg}^{2+}, \mathrm{Cl}$ and $\mathrm{SO}_{4}^{2-}$ (Fig. 3) is probably associated with the sample preparation techniques. The high concentration of $\mathrm{Mg}^{2+}$ ( or $\mathrm{Ca}^{2+}$ ) in such types of waters causes the precipitation of some minerals of $\mathrm{Mg}^{2+}$ (e.g., $\mathrm{MgCl}_{2}, \mathrm{MgSO}_{4}$, or some mixed minerals).

\section{Estimates of uncertainty in geochemical measurements}

The uncertainty of measurements in the geochemical analysis of geothermal waters is, generally, not reported in the scientific literature. However, the dispersion among the values of a chemical parameter measured by

\begin{tabular}{lll}
\hline Eq.No.* & $\begin{array}{l}\text { Temperature (K) with } \\
\text { uncertainty }\end{array}$ & $\begin{array}{l}\text { Vapor Fraction with } \\
\text { uncertainty }\end{array}$ \\
\hline 1. First value & $5.6(2) \mathrm{E} 2$ & $4.2(3) \mathrm{E}-1$ \\
1. Second value & $6.37(5) \mathrm{E} 2$ & $1.7(6) \mathrm{E}-1$ \\
2. & $5.6(1) \mathrm{E} 2$ & $4.2(3) \mathrm{E}-1$ \\
3. & $5.7(2) \mathrm{E} 2$ & $4.1(3) \mathrm{E}-1$ \\
4. & $5.6(2) \mathrm{E} 2$ & $4.3(3) \mathrm{E}-1$ \\
\hline *The quartz solubility equations, 1 to 4, are taken from Verma (2003), Verma \\
(2002), Gunnarsson and Arnórsson (2000), and Fournier and Potter (1982), respec- \\
tively. The equation 1 provides two values of temperature. The first value is similar \\
to the result obtained with other equations of quartz geothermometers
\end{tabular}

Table 5.- Calculated temperature and vapor fraction in the reservoir at the well AZ-5 of Los Azufres geothermal field.

Tabla 5.- Temperatura y fracción de vapor calculadas en el yacimiento del pozo AZ-5 del campo geotérmico Los Azufres. 
the participating laboratories during the inter-laboratory comparisons was observed to be relatively high. Thus, it is crucial to know the uncertainty of measurements in geochemical analysis and its propagation in any geochemical calculations in order to understand the reliability of results obtained from the data.

Figure 4 shows the box and whisker plots for $\mathrm{pH}, \mathrm{Na}^{+}$, $\mathrm{K}^{+}, \mathrm{Ca}^{2+}, \mathrm{Mg}^{2+}, \mathrm{Li}^{+}, \mathrm{Cl}^{2}, \mathrm{HCO}_{3}^{-}, \mathrm{SO}_{4}^{2-}, \mathrm{SiO}_{2}$ and $\mathrm{B}$. The samples (IAEA01 to IAEA13) are designated as 1 to 13 , respectively. The sample 0 is a geothermal water sample taken from Ellis (1976).

A curve was fitted between the mean $(x)$ and the coefficient of variation, C.V. (i.e. \% uncertainty of measurement) of each parameter for all the samples. The uncertainty of measurement increases exponentially with decreasing concentration for all the parameters except for $\mathrm{pH}$ and $\mathrm{SiO}_{2}$, and the uncertainty is in the same order of magnitude for concentrations lower than $1 \mathrm{mg} / \mathrm{kg}$. There is high dispersion between the fitted curve and experimental values (Fig. 4). Such a high dispersion may be affected by many factors: number of participating laboratories, different analytical methods used in the laboratories, earlier samples used older methods that have since been improved, and others. However, it is well established that there is higher percentage uncertainty in measuring low concentration than in measuring high concentration of chemical species in a water sample. The linear and exponential tendencies are two extreme cases of such behaviors. The exponential curve fitting is based on this criterion, while a more appropriate type of curve fitting remains to be developed (Verma, 2008a).

It can be observed in Figure 4 that the coefficient of correlation is generally very low even in case of linear fitting for $\mathrm{pH}$ and $\mathrm{SiO}_{2}$. Indeed, there is very little confidence in concluding any inference using these data; however, it reflects worldwide necessity to improve the analytical data quality. A systematic study with new comparisons may provide some clues for the causes of such dispersion. Another aspect to reduce the dispersion is the revision of analytical methods of individual laboratories (Verma, 2004).

Recently, Verma et al. (2012) conducted an inter-laboratory comparison of the analysis of $\mathrm{SiO}_{2}$ using commercial standards as water samples. They proposed a procedure to improve the analytical data quality; however, their results were similar as reported in the earlier interlaboratory comparisons.

There are two aspects to be considered in any geochemical study: the error (or uncertainty) in analytical data and its propagation in the calculated parameters. The second aspect is discussed here onwards. There is no relation between $p H$ and C.V.; however, the average uncertainty in the measurement of $p H$ is $\pm 2.5 \%$. Similarly, the average uncertainty for $\mathrm{SiO}_{2}$ is $\pm 10 \%$. These values of uncertainty for $\mathrm{pH}$ and $\mathrm{SiO}_{2}$ are used to propagate in the geochemical calculation. For other species, the fitted curves are used here to propagate analytical uncertainty in the geochemical calculations in the geothermal systems.

\section{Geochemical modelling of Los Azufres geothermal system}

Verma (2008a) presented a procedure to calculate the geothermal reservoir $p H$ using the two methods for the propagation of uncertainty (Kessel, 1999): uncertainty interval and GUM (Abbreviation of "Guide to the expression of Uncertainty in Measurement"). The uncertainty interval method is easy to apply. Kessel (1999) presented the limitations of this method and proposed a new method which is known as GUM. So, the GUM method will be applied here to propagate analytical uncertainty in the calculation of geothermal reservoir parameters. The calculation of reservoir $p H$ and its uncertainty propagation was presented without considering the uncertainty in the measured reservoir enthalpy (Verma, 2008a); however, there is need to modify the algorithm to propagate the measured enthalpy uncertainty.

Table 4 presents the physical-chemical parameters of the well AZ-5 of Los Azufres geothermal field (Tello, 2005). The analytical uncertainty for the parameters is not given; therefore, the relations between the concentration and the corresponding uncertainty derived above for the IAEA geothermal waters will be used here. The uncertainty in the measured enthalpy is considered as $2 \%$.

Verma (2008b) presented a conceptual diagram of geothermal system for sample collection and chemical analysis of geothermal fluids. The order of separators is inverted in the present computer code that was presented by Verma (2008b). It is easy to program the error propagation in the present order of separators. As the geothermal fluid flows upward in a well, it flashes within the well and in the separators. The first separator can be a weir box or a separator at the condition of separation pressure different from the atmospheric pressure. If the pressure at the separator is higher than the atmospheric pressure, the separated water is passed through a cooling coil attached to the separator to collect the sample. The reconstruction of deep reservoir chemical composition in the vapor and liquid phases is possible through the conservation of mass, enthalpy, alkalinity and the distribution coefficient of certain species between the vapor and liquid phases (Verma and Truesdell, 2001). 


\subsection{Calculation of temperature and vapor fraction in the reservoir}

Verma (2008b) presented an algorithm to calculate the deep reservoir temperature and vapor fraction with the quartz solubility geothermometry. There are four conditions of geothermal reservoir fluid to obtain water and vapor in a well separator: (i) liquid only along the saturation curve, (ii) liquid-vapor along the saturation curve, (iii) liquid along the saturation curve which lost some vapor before reaching the surface, and (iv) liquid in the compressed liquid region. The first three situations are described in any textbook on the fluid geochemistry of geothermal systems (e.g., Henley et al., 1984); however, the liquid geothermometry is applied only considering the first situation in which there is only liquid along the saturation curve in the reservoir. In other words, the energy of conservation has not been considered in the liquid geothermometry. Verma (2008b) revised the algorithm considering the conservation of mass and energy for the first three situations using the four equations: (i) a quadratic equation of $1 / \mathrm{T}(\mathrm{K})$ and $\mathrm{P}(\mathrm{MPa})$ (Verma, 2003). (ii) a linear equation relating $\log \left(\mathrm{SiO}_{2}\right)$ to the inverse of absolute temperature (Verma, 2002), (iii) a polynomial of absolute temperature including logarithmic terms (Gunnarsson and Arnórsson, 2000) and (iv) temperature as a polynomial of $\mathrm{SiO}_{2}$ including logarithmic terms (Fournier and Potter, 1982). Here the algorithm is modified including the propagation of uncertainty of the measured enthalpy (2\%) and $\mathrm{SiO}_{2}$ concentration (10\%) for all the four quartz solubility equations.

Arras (1998) presented the derivation of error (uncertainty) propagation law and illustrated the complications associated with the non-linearity of system. The equations of uncertainty propagation are expressed in matrix notation as

$$
C_{Y}=F_{X} C_{X} F_{X}^{T}
$$

where $C_{Y}$ is the $p \times p$ output covariance matrix, $F_{X}$ is a $p \times n$ Jacobian matrix of a p-dimensional vector-valued function $f(X)=\left[f_{1}(X) f_{2}(X) \ldots f_{p}(X)\right]^{T}$, and $C_{X}$ is $n \times n$ input covariance matrix which contains all variances and covariances of the input random variables, $X_{1}, X_{2}, \ldots X_{n}$. If the $X_{i}$ 's are independent, all $\sigma_{i j}$ with $i \neq j$ disappear and $C_{X}$ is diagonal. This algorithm will be included in the computer program, QrtzGeotherm (Verma, 2012). In our system the independent variables are reservoir enthalpy ( $\mathrm{Hr}$ ) and total discharge concentration of $\mathrm{SiO}_{2}$ $\left(\mathrm{SiO}_{2} \mathrm{TD}\right)$, whereas the dependent variables are reservoir temperature (TRes) and vapor fraction (yRes). Firstly, we have propagated the uncertainty in the measured $\mathrm{SiO}_{2}$ to $\mathrm{SiO}_{2} \mathrm{TD}$.

Table 5 presents the values of temperature and vapor fraction with their respective uncertainties in the reser- voir of Los Azufres geothermal field. It can be observed that the first values of temperature and vapor fraction for the quadratic equation are similar to the corresponding values for other geothermometer equations. However, there are two values of temperature and vapor fraction for equation 1. Verma et al. (2006) demonstrated in the case of Cerro Prieto geothermal field that the second value of equation 1 was close to the measured temperature in some wells. There is high uncertainty in the values of temperature and vapor fraction. In other words, there is high uncertainty in the characteristics of geothermal reservoir, obtained on the geochemical evidences.

\section{Conclusions}

All the statistical data treatment methods reveal high analytical uncertainty in the geochemical analysis of geothermal waters. The single-outlier type multiple test method involving Dixon, Grubbs, skewness and kurtosis tests at 99\% confidence level is used for the calculation of analytical uncertainty in the geochemical analysis. The distribution of standards as samples together with natural waters in the inter-laboratory comparison is fundamental to obtain accurate and precise analytical data for geothermal waters.

A multivariate uncertainty propagation method is proposed based on the error (uncertainty) propagation law for the calculation of uncertainty in the geothermal reservoir parameters. The analytical uncertainty in the reservoir temperature calculated with quartz solubility geothermometer is $\pm 20 \mathrm{~K}$. Thus the improvement of geochemical analysis of geothermal water is first necessity to understand the characteristics of geothermal systems with fluid geochemistry.

The analyses of $\mathrm{Na}^{+}$and $\mathrm{K}^{+}$are sufficiently precise and accurate; there is high uncertainty in the analyses of other parameters. This study emphasizes both accuracy and uncertainty in the analysis of geochemical parameters. There is need to improve the analytical quality of $\mathrm{Mg}^{2+}, \mathrm{Li}^{+}, \mathrm{HCO}_{3}^{-}$and $\mathrm{SiO}_{2}$ for reliable geochemical modelling of geothermal systems. The uncertainty in the measured reservoir enthalpy is considered here as $\pm 2 \%$, which needs to be validated.

\section{Acknowledgements}

The author highly appreciates Surendra P. Verma for providing the computer program DODESSYS and fruitful discussion on the single-outlier type multiple test method involving Dixon, Grubbs, skewness and kurtosis tests at $99 \%$ confidence level. The paper is substantially improved with the constructive comments 
and suggestions of the reviewers, Richard Glover and Guima A. Urbino.

\section{APPENDIX A. SUPPLEMENTARY DATA}

The analytical data of all the samples (IAEA01 to IAEA14), distributed during the IAEA inter-laboratory calibration programs are compiled in an Excel Workbook, which can be obtained on request to the author.

\section{References}

Abbey, S. (1979a): "Rock analysis" methods at the Geological Survey of Canada. Geostandards Newsletter 3, 97-101.

Abbey, S. (1979b): Reference materials - rock samples SY-2, SY3, MRG-1. Report of the Energy, Mines and Resources, Canada.

Alvis-Isidro, R., Urbino, G.A., Gerardo-Abaya, J. (1999): 1999 interlaboratory comparison of geothermal water chemistry under IAEA regional project RAS/8/075. Report, IAEA, Vienna: 39 p.

Alvis-Isidro, R., Urbino, G.A., Pang, Z. (2000): Results of the 2000 IAEA interlaboratory comparison of geothermal water chemistry. Report, IAEA, Vienna, 40 p.

Alvis-Isidro, R., Urbino, G.A., Pang, Z. (2002): 2001 interlaboratory comparison of geothermal water chemistry. Report, IAEA, Vienna, $55 \mathrm{p}$.

AMC (Analytical Methods Committee) (2001): AMC technical brief: Robust statistics: a method of coping with outliers. http:/ www.rsc.org/lap/rsccom/amc/amc_index. htm.

Araguás, L., Rozanski, K. (1995): IAEA interlaboratory comparison for deuterium and oxygen-18 analysis of precipitation samples. Report, IAEA, Vienna, $33 \mathrm{p}$.

Arras, K.O., (1998): An introduction to error propagation: derivation, meaning and examples of equation $C_{Y}=F_{X} C_{X} F_{X}^{T}$, Technical report EPEL-ASL-TR-98-01 R3, Swiss Federal Institute of Technology Lausanne, http://www.nada.kth.se/ kai-a/papers/ arrasTR-9801-R3.pdf.

Barnett, V., Lewis, T. (1994): Outliers in Statistical Data. Third edition, John Wiley, Chichester, 584 p.

Dybczyński, R. (1980): Comparison of the effectiveness of various procedures for the rejection of outlying results and assigning consensus values in interlaboratory programs involving determination of trace elements or radionuclides. Analytica Chimica Acta 117, 53-70.

Dybczyński, R., Tugsavul, A., Suschny, O. (1979): Soil-5, a new IAEA certified reference material for trace element determinations. Geostandards Newsletter 3, 61-87.

Ellis, A.J. (1976): The IAGC interlaboratory water analysis comparison programme. Geochimica et Cosmochimica Acta 40, 1359-1374. doi:10.1016/j.bbr.2011.03.031.

Fairbairn, H.W., and others, 1951, A cooperative investigation of precision and accuracy in chemical, spectrochemical, and modal analysis of silicate rocks: United States Geological Survey Bulletin $80,71 \mathrm{p}$.

Flanagan, F.J. (1967): U.S. Geological Survey silicate rock standards. Geochimica et Cosmochimica Acta 31, 289-308.

Flanagan, F.J. (1986a): Rock reference samples, San Marcos Gabbro, GSM-1 and Lakeview Mountain Tonalite, TLM-1. Geostandards Newsletter 10, 111-119.

Flanagan, F.J. (1986): Reference samples in geology and geochemistry. Geostandards Newsletter 10, 191-264.

Fournier, R.O., Potter, R.W. (1982): A revised and expanded silica (quartz) geothermometer. Geothermal Resource Council Bulletin 11, 3-12.

Fournier, R.O., Truesdell, A.H. (1973): An empirical Na-K-Ca geothermometer for natural waters. Goechimica et Cosmochimica Acta 37, 1255-1275.

Gerardo-Abaya, J., Schueszler, C., Groening, M. (1998): Results of the interlaboratory comparison for water chemistry in natural geothermal samples under RAS/8/075. Report, Vienna, IAEA, $18 \mathrm{p}$.

Giggenbach, W.F., Goguel, R.L., Humphries, W.A. (1992): IAEA interlaboratory comparative geothermal water analysis program. Geothermal Investigations with Isotope and Geothermal Techniques in Latin America, IAEA-TECDOC-641, Vienna, 439-456.

Gladney, E.S. (1981): Comparison of methods for calculation of recommended elemental concentrations for Canadian certified reference materials project rock standards SY-2, SY-3, and MRG-1. Los Alamos Scientific Laboratory, University of California, Los Alamos, New Mexico, 4 p.

Gladney, E.S., Roelandts, I. (1988): 1987 compilation of elemental concentration data for USGS BIR-1, DNC-1 and W-2. Geostandards Newsletter 12, 63-118.

Gladney, E.S., Jones, E.A., Nickell, E.J., Roelandts, I. (1990): 1988 compilation of elemental concentration data for USGS basalt BCR-1. Geostandards Newsletter 14, 209-359.

Gladney, E.S., Jones, E.A., Nickell, E.J., Roelandts, I. (1991): 1988 compilation of elemental concentration data for USGS DTS-1, G-1, PCC-1, and W-1. Geostandards Newsletter 15, 199-396.

Govindaraju, K. (1980): Report (1980) on three GIT-IWG rock reference samples: anorthosite from Greenland, AN-G; basalte d' Essey-la-Côte, BE-N; granite de Beauvoir, MA-N. Geostandards Newsletter 4, 49-138.

Govindaraju, K. (1984): 1984 Compilation of working values for 170 international reference samples of mainly silicate rocks and minerals: main text and tables. Geostandards Newsletter 8, Special Issue, 3-16.

Govindaraju, K. (1994): 1994 Compilation of working values and sample description for 383 geostandards. Geostandards Newsletter 18, Special Issue, 1-158.

Govindaraju, K., De la Roche, H. (1977): Rapport (1966-1976) sur les eléments en traces dans trois roches standards géochimiques du CRPG: Basalte BR et Granites, GA et GH. Geostandards Newsletter 1, 67-100.

Guevara, M., Verma, S.P., Velasco-Tapia, F. (2001): Evaluation of GSJ intrusive rocks JG1, JG2, JG3, JG1a, and JGb1 by an objective outlier rejection statistical procedure. Revista Mexicana de Ciencias Geológicas 18, 74-88.

Gunnarsson, I., Arnórsson, S., (2000): Amorphous silica solubility and the thermodynamic properties of $\mathrm{H}_{4} \mathrm{SiO}_{4}{ }^{0}$ in the range $0^{\circ}$ to $350^{\circ} \mathrm{C}$ at $\mathrm{P}_{\text {sat }}$. Geochimica et Cosmochimica Acta 64, 2295-2307. doi: $10.1016 / j . b b r .2011 .03 .031$.

Harvey, D. (2000): Modern Analytical Chemistry. McGraw Hill, Boston, $816 \mathrm{p}$.

Hayes, K., Kinsella, A., Coffey, N. (2007): A note on the use of outlier criteria in Ontario laboratory quality control schemes. Clinical Biochemistry 40, 147-152. doi: 10.1016/j.clinbiochem.2006.08.0

Henley, R.W., Truesdell, A.H., Barton, P.B., Whitney, J.A. (1984): Fluid-mineral equilibria in hydrothermal systems. Society of Economic Geologists, El Paso, TX, 267 p.

Imai, N., Terashima, S., Itoh, S., Ando, A. (1996): Database on internet for geological survey of Japan geochemical reference samples. Geostandards Newsletter 20, 161-164.

Kessel, W. (1999): ISO/BIPM guide: uncertainty of measurement, http://www.metrodata.ed/papers/resistor en.pdf, $16 \mathrm{p}$.

Lippmann, J., Gröning, M., Rozanski, K. (1999): $2^{\text {nd }}$ interlabora- 
tory comparison for deuterium and oxygen-18 analysis of water samples. Report, IAEA, Vienna, 32 p.

Marroquín-Guerra, S.G., Velasco-Tapia, F., Díaz-González, L. (2009): Evaluación estadística de Materiales de Referencia Geoquímica del Centre de Recherches Pétrographiques et Géochimiques (Francia) aplicando un esquema de detección y eliminación de valores desviados. Revista Mexicana de Ciencias Geológicas 26, 530-542.

Pandarinath, K. (2009): Evaluation of geochemical sedimentary reference materials of the Geological Survey of Japan (GSJ) by an objective outlier rejection statistical method. Revista Mexicana de Ciencias Geológicas 26, 638-646.

Parr, R.M., Clements, S.A. (1991): Intercomparison of enriched stable isotope reference materials for medical and biological studies. Report, IAEA, Vienna, $31 \mathrm{p}$.

Potts, P.J., Tindle, A.G., Webb, P.C. (1992): Geochemical reference material compositions. Caithness, UK, WP - CRC, 313 p.

Stanley, D.L. (1995): Standard procedures and quality-control practices for the U.S. Geological Survey national field quality assurance program from 1982 through 1993. U.S. Geological Survey Open-File Report 95-317, 75 p.

Steele, T.W. (1978): A guide to the reporting of analytical results relating to the certification of geological reference materials. Geostandards Newsletter 2, 31-33.

Tello, E. (2005): Estado de equilibrio soluto-mineral y saturación de minerales de alteración en fluido geotérmicos de alta temperatura de México, Ph.D. Thesis, Facultad de Ingeniería, División de estudios de posgrado, Universidad Nacional Autónoma de México, $271 \mathrm{p}$.

Urbino, G.A., Pang, Z. (2004): 2003 interlaboratory comparison of geothermal water chemistry. Report, PNOC, Philippines, $51 \mathrm{p}$.

Velasco, F., Verma, S.P., Guevara, M. (2000): Comparison of the performance of fourteen statistical tests for detection of outlying values in geochemical reference material databases. Mathematical Geology 32, 439-464.

Velasco-Tapia, F., Guevara, M., Verma, S.P. (2001): Evaluation of concentration data in geochemical reference materials. Chemie der Erde 61, 69-91.

Verma, M.P. (2002): Geochemical techniques in geothermal development. in D. Chandrasekharam and J. Bundschuh (eds.) Geothermal Energy Resources for Developing Countries. The Swets \& Zeitlinger Publishers, Netherlands, 225-251.

Verma, M.P. (2003): QrtzGeotherm: a computer program for the quartz solubility geothermometer in moderately saline brines up to $370^{\circ} \mathrm{C}$. Geothermal Research Council Transactions 27, 341345.

Verma, M.P. (2004): A revised analytical method for $\mathrm{HCO}_{3}^{-}$and $\mathrm{CO}_{3}{ }^{2-}$ determinations in geothermal waters: an assessment of IAGC and IAEA interlaboratory comparisons. Geostandards and Geoanalytical Research 28, 391-409. doi:10.1111/j.1751908X.2004.tb00758.x.

Verma, M.P. (2008a): IAGC and IAEA Interlaboratory Comparisons of Geothermal Water Chemistry: the propagation of uncertainty in the reservoir $\mathrm{pH}$ calculation. Geostandards and Geoanalytical Research 32, 317-330. doi: 10.1111/j.1751-908X.2008.00832.x.

Verma, M.P. (2008b): QrtzGeotherm: An AcitveX component for the quartz solubility geothermometer. Computers \& Geosciences 34, 1918-1925. doi: 10.1016/j.bbr.2011.03.031.

Verma, M.P. (2010): IAEA inter-laboratory comparisons of geothermal water chemistry: a review on statistical data treatment approaches. Acta INAGEQ 16, 38-43.

Verma, M.P. (2012): QrtzGeotherm: A component in Visual Studio .Net for the quartz solubility geothermometer with uncertainty propagation. Computers \& Geosciences 48, 316-333. doi: 10.1016/j.bbr.2011.03.031

Verma, M.P., Arellano, V.M., Aguilar, K.M., (2006): QrtzGeotherm: An ActiveX component for the quartz solubility geothermometers. Proceedings NZ Geothermal Workshop.

Verma, M.P., Izquierdo, G., Urbino, G.A., Gangloff, S., Garcia, R., Aparicio, A., Conte, T., Armienta, M.A., Sanchez, M., Gabriel, J.R.P., Fajanela, I.D., Renderos, R., Acha, C.B.A., Prasetio, R., Grajales, I.C, Delgado, L.R., Opondo, K., Esparza, R.Z., Panama, L.A., Salazar, R.T., Lim, P.G., Javino, F. (2012): Inter-laboratory comparison of $\mathrm{SiO}_{2}$ analysis for geothermal water chemistry. Geothermics 44, 32-42. doi:/10.1016/j.bbr.2011.03.031.

Verma, M.P., Tello, E., Sandoval, F., Tovar, R., Martinez, J.L. (2002): An interlab calibration of silica for geothermal water chemistry. Geothermics 31, 677-686. doi:10.1016/j.bbr.2011.03.031

Verma, M.P., Truesdell, A.H. (2001): pH calculation through the use of alkalinity in geochemical modeling of hydrothermal systems. In (ed.) Rosa Cidu, Water-Rock Interaction, A.A. Balkema Publishers, Tokyo, 217-220.

Verma, S.P. (1997): Sixteen statistical tests for outlier detection and rejection in evaluation of International Geochemical Reference Materials: example of microgabbro PM-S. Geostandards Newsletter. The Journal of Geostandards and Geoanalysis 21, 59-75.

Verma, S.P. (1998): Improved concentration data in two international geochemical reference materials (USGS basalt BIR-1 and GSJ peridotite JP-1) by outlier rejection. Geofísica Internacional $37,215-250$.

Verma, S.P., Díaz-González, L. (2012): Application of the discordant outlier detection and separation system in the geosciences: International Geology Review 54, 593-614. doi: 10.1080/00206814.2011.569402.

Verma, S.P., Quiroz-Ruiz, A. (2006a): Critical values for six Dixon tests for outliers in normal samples up to sizes 100, and applications in science and engineering. Revista Mexicana de Ciencias Geológicas 23, 133-161.

Verma, S.P., Quiroz-Ruiz, A. (2006b): Critical values for 22 discordancy test variants for outliers in normal samples up to sizes 100 , and applications in science and engineering. Revista Mexicana de Ciencias Geológicas 23, 302-319.

Verma, S.P., Quiroz-Ruiz, A. (2008): Critical values for 33 discordancy test variants for outliers in normal samples of very large sizes from 1,000 to 30,000 and evaluation of different regression models for the interpolation of critical values. Revista Mexicana de Ciencias Geológicas 25, 369-381.

Verma, S.P., and Quiroz-Ruiz, A. (2011): Corrigendum to Critical values for 22 discordancy test variants for outliers in normal samples up to sizes 100, and applications in science and engineering [Rev. Mex. Cienc. Geol., 23 (2006), 302-319]: Revista Mexicana de Ciencias Geológicas 28, 202.

Verma, S.P., Santoyo, E. (1997): New improved equations for $\mathrm{Na} / \mathrm{K}$, $\mathrm{Na} / \mathrm{Li}$, and $\mathrm{SiO} 2$ geothermometers by outlier detection and rejection. Journal of Volcanology and Geothermal Research 79, 9-23. doi:10.1016/S0377-0273(97)00024-3.

Verma, S.P., Quiroz-Ruiz, A., Díaz-González, L. (2008a): Critical values for 33 discordancy test variants for outliers in normal samples up to sizes 1000, and applications in quality control in Earth Sciences. Revista Mexicana de Ciencias Geológicas 25, 82-96.

Verma, S.P., Pandarinath, K., Santoyo, E. (2008b): SolGeo: A new computer program for solute geothermometers and its applications to Mexican geothermal fields. Geothermics 37, 597-621. doi:10.1016/j.bbr.2011.03.031.

Verma, S. P., L. Díaz-González, R. González-Ramírez (2009): Relative efficiency of single-outlier discordancy tests for processing geochemical data on reference materials and application to instrumental calibration by a weighted least-squares linear regres- 
sion model. Geostandards and Geoanalytical Research 33, 2949. doi: 10.1111/j.1751-908X.2009.00885.x

WDNR (Wisconsin Department of Natural Resources) (1996): Analytical detection limit guidance and laboratory guide for determining method detection limits. Wisconsin Department of Natural Resources, Laboratory Certification Program PUBLTS-056-96, 29p. 